\title{
Proxy analysis of hospital admissions due to colorectal cancer and Schistosoma mansoni incidence
}

\author{
Análise proxy de internações por câncer colorretal e incidência de Schistosoma \\ Mansoni \\ Gustavo Fernandes Godoy Almeida ${ }^{1,2}$, Mauricio Assuero Lima de Freitas³, Lais Neares Barbosa \\ Ribeiro', Mariana Montenegro de Melo Lira ${ }^{4}$, Maxwell Alex de Lima Moura', Lauro Vinicius \\ Machado da Silva², Luiz Alberto Reis Mattos Jr' ${ }^{1}$, Ana Lucia Coutinho Domingues ${ }^{5}$
}

\begin{abstract}
Schistosoma has been associated with colorectal cancer. We compared the number of colorectal cancer admissions between those cities in the state of Pernambuco with and without schistosomiasis. We abstracted data from Datasus and analyzed the number of admissions due to CRC in those cities with (CRC/Schistosoma) and without schistosomiasis (CRC-alone) in the State of Pernambuco and compared these numbers using odds ratio and relative risk at a significance level of $5 \%$. This was preceded by an $\mathrm{F}$ test to reject the null hypothesis that the number of cities in each group was the same. The mean number of admissions due to CRC in CRC-Schistosoma cities was 94.55 , with a variability of $366 \%$, while in CRC-alone cities the mean was 11.06 , with a variability of $88 \%$. A test at a significance level of $5 \%$ rejected the hypothesis that these variances were the same (p-value, 0.0000). A subsequent test also rejected the null hypothesis that the mean of admissions was the same (two-sided p-value 0.0167). The state of Pernambuco encompasses 184 cities of which 103 registered schistosomiases (102 with colorectal cancer and 1 without). We compared the number of admissions due to CRC and/or due to schistosomiasis with admissions due to other diseases to measure the odds ratio for colorectal cancer due to schistosomiasis exposure. This comparison resulted in an OR of 2.657 (Cl $95 \% 2,478-2,849$ ) for CRC due to exposure to schistosomiasis. We found a statistically significant correlation between colorectal cancer admissions and schistosomiasis in the state of Pernambuco. Pharmacoeconomic studies might proof if investment to prevent nematode infestation would translate into cost spare with less admissions due to cancer and cancer treatments.
\end{abstract}

Keywords: Schistosoma; Schistosoma mansoni; Colorectal Neoplasms; Carcinogenesis; Patient Admission

\footnotetext{
1. Hospital das Clinicas Universidade Federal de Pernambuco, Clinical Oncology - Recife - PE - Brazil.

2. Centro Universitário Mauricio de Nassau, Medicine - Recife - PE - Brazil.

3. Universidade Federal de Pernambuco, Fundação de Apoio ao Desenvolvimento da UFPE - Recife - PE - Brazil

4. Hospital das Clinicas Universidade Federal de Pernambuco, Pathology - Recife - PE - Brazil.

5. Hospital das Clinicas Universidade Federal de Pernambuco, Gastroenterology - Recife - PE - Brazil.
}

Financial support: none to declare.

Conflicts of interest: The authors declare no conflict of interest relevant to this manuscript.

Corresponding author: Gustavo Godoy Almeida. Hospital das Clinicas Universidade Federal de Pernambuco. Av. Professor Moraes Rego,

no 1235, Cidade Universitária, Recife - PE. Zip-code: 50670-901. E-mail: godoy.onco@gmail.com

Received on: October 1, 2018 | Accepted on: November 29, 2018

DOI: $10.5935 / 1806-6054.20180005$ 


\section{RESUMO}

O Schistosoma tem sido associado ao câncer colorretal. Comparamos o número de internações por câncer colorretal entre aquelas cidades do estado de Pernambuco com e sem esquistossomose. Extraímos dados do Datasus e analisamos o número de internações devidas a CRC naquelas cidades com esquistossomose (CRC/Schistosoma) e sem ela (CRC-apenas) no Estado de Pernambuco e comparamos estes números usando odds ratio e risco relativo com um nível de significância de 5\%. Isso foi precedido por um teste F para rejeitar a hipótese nula de que o número de cidades em cada grupo era o mesmo. O número médio de admissão devido a CRC em cidades CRC-Schistosoma foi 94,55, com uma variabilidade de 366\%, enquanto que nas cidades CRC-apenas, a média foi de 11,06, com uma variabilidade de $88 \%$. Um teste com um nível de significância de $5 \%$ rejeitou a hipótese de que essas variâncias fossem as mesmas (valor p, 0,0000). Um teste subsequente também rejeitou a hipótese nula de que a média de internações era a mesma (valor p bicaudal 0,0167). O estado de Pernambuco abrange 184 cidades, das quais 103 registraram esquistossomose (102 com câncer colorretal e 1 sem). Comparamos o número de internações devido a CRC e/ou devido a esquistossomose com aquele de admissões devidas a outras doenças para medir o odds ratio para câncer colorrectal por exposição à esquistossomose. Essa comparação resultou em um OR de 2.657 (IC 95\% 2.478-2.849) para o CCR devido à exposição à esquistossomose. Encontramos uma correlação estatisticamente significativa entre as internações por câncer colorretal e a esquistossomose no estado de Pernambuco. Estudos farmacoeconômicos poderiam comprovar se o investimento para prevenir a infestação por nematódeos se traduziria em custo menor com menos admissões devido ao câncer e seu tratamento.

Descritores: Schistosoma; Schistosoma mansoni; Neoplasias Colorretais; Carcinogênese; Admissão de Paciente

\section{INTRODUCTION}

Schistosomiasis is caused by nematode worms of the Schistosoma genus, including Schistosoma mansoni, Schistosoma japonicum, and Schistosoma haematobium as the main species. It is an endemic disease in tropical and subtropical regions. ${ }^{(1)}$ At least 230 million people worldwide are infested with Schistosoma species. ${ }^{(2)}$ In Brazil, approximately 25 million people live in areas at risk for S. mansoni. ${ }^{(3)}$

It has been published that $\mathrm{S}$. japonicum is associated with liver and colorectal cancer (CRC) $)^{(4-6)}$ and S. haematobium with bladder cancer. ${ }^{(7)}$ Evidence for the association between S. mansoni and CRC is scarce. ${ }^{(8)}$ Recently, our research group has reported two young patients with colorectal cancer and schistosomiasis in whom microsatellite instability and RAS mutation have been identified. ${ }^{(9)}$

Whether Schistosoma induces carcinogenesis is not clear yet. Hanahan and Weinberg have proposed six hallmarks of cancer that they define as "distinctive and complementary capabilities that enable tumor growth and metastatic dissemination."(10) These include sustained proliferative signaling, evading growth suppressors, resisting cell death, enabling replicative immortality, inducing angiogenesis, and activating invasion and metastasis. In addition to these six hallmarks, Hanahan and Weinberg outline two emerging hallmarks and two enabling characteristics that make it possible for tumor cells to acquire the core hallmarks. The two emerging hallmarks are deregulating cellular energetics and avoiding immune destruction. The two enabling characteristics are properties of cancer cells that facilitate the acquisition of the hallmarks. The first of these characteristics is genomic instability, which enables the acquisition of the multiple mutations required for multistep tumorigenesis. The second enabling characteristic is tumor-promoting inflammation, which reflects the rapidly advancing concept that inflammatory responses can actually facilitate tumor initiation and progression in some contexts. Schistosoma eggs accumulate in the submucosa of the colon and induce inflammation, nodules, polyps, and hyperplasia. ${ }^{(4)}$

The aim of this study is to compare the number of admissions due to CRC between cities with (CRC/Schistosoma) and without schistosomiasis (CRC-alone) incidence (not only admission) to add light to this possible Schistosoma associated carcinogenesis. 


\section{METHODS}

Data were abstracted from DATASUS, which is Brazilian National Health Care System database providing information on admissions, mortality, hospital stay length and costs (www.datasus.gov.br). We abstracted data on the number of admissions due to CRC in those cities with (CRC/Schistosoma) and without schistosomiasis (CRC-alone) in the State of Pernambuco and compared these numbers using odds ratio and relative risk at a significance level of $5 \%$. Only cities with either colorectal cancer or/and schistosomiasis were included in this analysis. CRC patients were segregated into exposed and not exposed to schistosomiasis.
We also compared the number of admissions due to CRC and/or to schistosomiasis with admissions due to other diseases (different from Schistosoma and colorectal cancer). The study used statistical inference to compare admission means of CRC/Schistosoma and CRC-alone cities, using chi-square and odds ratio. This was preceded by an F test, considering $F_{(101.78)}=1275.57$ ( $p$-value 0.0000$)$, to reject the null hypothesis that the number of cities in each group was the same. This is the first publication using this method of abstraction from DATASUS correlating colorectal cancer and schistosomiasis.

\section{RESULTS}

From January 2008 until November 2017, 2444 admissions due to schistosomiasis occurred in Brazil and $54.05 \%$ were registered in the Northeast Region, which encompasses nine states. In the state of Pernambuco 586 admissions were registered, representing $24.10 \%$ of the country and $44.45 \%$ of Northeast Region. In terms of admissions due to $\mathrm{CRC}$, in the same period, the state of Pernambuco registered 10,524 admissions and a mean per city of 4.78 in 2008 and 12.32 in 2017. The mean number of admissions due to CRC in CRC-Schistosoma cities was 94.55, with a variability of $366 \%$, while in CRCalone cities the mean was 11.06 , with a variability of $88 \%$. A test at a significance level of $5 \%$ rejected the hypothesis that these variances were the same (p-value, 0.0000). A subsequent test also rejected the null hypothesis that the mean of admissions was the same (two-sided p-value 0.0167, Table 1).

The state of Pernambuco encompasses 184 cities of which 103 registered schistosomiasis (102 with colorectal cancer and 1 without it). We hypothesized that the odds ratio for admissions due to colorectal cancer would be higher in those cities with schistosomiasis than in those cities without both diseases. This comparison resulted in an OR of 2.657 (Cl 95\% 2,478-2,849) for CRC and exposure to schistosomiasis (Table 2).

The study cannot answer if cancer mortality rate was higher among those exposed to schistosomiasis versus those who were not because of 85 out of 103 cities did not report the number of deaths.

Table 1. Comparison of admission means between CRC-Schistosoma and CRC-alone cities using T-Test

\begin{tabular}{l|c|c}
\hline & CRC-Schistosoma & CRC-alone \\
\hline Mean & 94.55 & 11.06 \\
\hline Variance & $119,865.52$ & 94.26 \\
\hline Number of cities & 102 & 79 \\
\hline Null hypothesis & 0 & \\
\hline gl & 101 & \\
\hline Stat $t$ & 2.434 & \\
\hline $\mathrm{P}(T<=\mathrm{t})$ one-sided & 0.0083 & \\
\hline One-sided $\mathrm{P}(\mathrm{T}<=\mathrm{t})$ two-sided & 1.6601 & \\
\hline Two-sided $\mathrm{t}$ & 0.0167 & \\
\hline
\end{tabular}

Table 2. odds ratio for CRC due to schistosomiasis exposure

\begin{tabular}{l|c|c|c}
\hline & \multicolumn{2}{|c|}{ Schistosomiasis } \\
\hline CRC & Yes & No & Total \\
\hline Yes & 9667 & 857 & 10524 \\
\hline No & 4249483 & 1000925 & 5250408 \\
\hline Total & 4259150 & 1001787 & 5260932 \\
\hline
\end{tabular}




\section{DISCUSSION}

A study of liver and colon cancers and their association with a previous diagnosis of schistosomiasis was performed in China. The authors analyzed 127 liverand 142 colorectal-cancer patients, each matched with one or two controls. Given the extremely strong association between hepatitis and liver cancer in China, only data from hepatitis-negative pairs were included in the analysis. Schistosomiasis was associated with both liver cancer (OR 3.7; 95\% CI 1.0-13) and colorectal cancer (OR 3.3; 95\%Cl 1.8-6.1). ${ }^{(11)}$ This publication is in accordance with our study that shed light over the potential relation between colorectal cancer admissions and schistosomiasis. This is the first publication to suggest that admissions due to colorectal cancer with schistosomiasis are greater than those without that association. Should patients with CCR-Schistosoma be frailer than those with CCR only and if this fact influence either over admissions or mortality is as issue of debate.

Some questions may arise: 1) How many patients with schistosomiasis develop colorectal cancer? Would nematode infestation avoidance decrease the incidence of cancer? In which amount? To treat chronic inflammation would be enough? From which age should we start screening at? Which schistosomiasis form? Only intestinal? Might Schistosoma mansoni hepatic form promote liver cancers? Are admissions an indirect sign of increased mortality? Does stage II and III colorectal cancer have increased or decreased risk to justify starting or avoiding adjuvant chemotherapy? Does hypersplenism preclude adjuvant chemotherapy? This study may stimulate further research either in Brazil or in other Schistosoma-endemic countries to answer part of these questions.

Should the hypothesis of a relation between colorectal cancer and schistosomiasis be true, we are facing a subgroup of potentially avoidable colorectal cancers. Pharmacoeconomic studies might proof if investment to prevent nematode infestation would translate into cost spare with less admissions due to cancer and cancer treatments. Our group will test schistosomiasis-associated colorectal cancers to describe carcinogenesis steps and compare this genetic profile with sporadic colorectal cancers.

One limitation of this observational study is that confounder variables such as other risk factors for colorectal cancer should have been tested. However, prevalence of inflammatory bowel disease and obesity, as well as access to colorectal cancer screening are not available at DATASUS.

In conclusion, a higher number of colorectal cancer admissions in the state of Pernambuco was observed in the cities where schistosomiasis was also present when compared with the cities with colorectal cancer without schistosomiasis. The number of admissions due to colorectal cancer in those cities with schistosomiasis was also higher than the admissions due to causes other than colorectal cancer or/and schistosomiasis.

\section{REFERENCES}

1. Hosho K, Ikebuchi Y, Ueki M, Nakamura K, Yashima K, Maeda N, et al. Schistosomiasis japonica identified by laparoscopic and colonoscopic examination. Dig Endosc. 2010;22(2):133-6.

2. Colley DG, Bustinduy $A L$, Secor WE, King $\mathrm{CH}$. Human schistosomiasis. Lancet. 2014;383(9936):2253-64.

3. Brazil. Ministério da Saúde, Secretaria de Vigilância em Saude: Guia de Vigilância Epidemiológica, $7^{\text {a }}$ ed. Brasília: Ministério da Saúde; 2012.

4. Gray DJ, Ross AG, Li YS, McManus DP. Diagnosis and management of schistosomiasis. BMJ. 2011;342:d2651.

5. Matsuda K, Masaki T, Ishii S, Yamashita H, Watanabe $T$, Nagawa $H$, et al. Possible associations of rectal carcinoma with Schistosoma japonicum infection and membranous nephropathy: a case report with a review. Jpn J Clin Oncol. 1999;29(11):576-81.

6. Liu W, Zeng HZ, Wang QM, Yi H, Mou Y, Wu CC, et al. Schistosomiasis combined with colorectal carcinoma diagnosed based on endoscopic findings and clinicopathological characteristics: A report on 32 cases. Asian Pac J Cancer Prev. 2013;14(8):4839-42.

7. Mostafa MH, Sheweita SA, O'Connor PJ. Relationship between schistosomiasis and bladder cancer. Clin Microbiol Rev. 1999;12(1):97-111.

8. Salim OE, Hamid HK, Mekki SO, Suleiman SH, Ibrahim SZ. Colorectal carcinoma associated with schistosomiasis: A possible causal relationship. World J Surg Oncol. 2010;8:68.

9. Almeida GFG, Sarinho FW, Lima PCA, Oliveira Filho JB, Moura MAL, Ribeiro LNB, et al. DNA repair defect and RAS mutation in two patients with Schistosoma mansoni-associated colorectal cancer: carcinogenesis steps or mere coincidence? J Glob Oncol. 2016;3(4):423-6.

10. Hanahan D, Weinberg R. Hallmarks of cancer: The next generation. Cell. 2011;144(5):646-74.

11. Qiu DC, Hubbard AE, Zhong B, Zhang Y, Spear RC. A matched, case-control study of the association between Schistosoma japonicum and liver and colon cancers, in rural China. Ann Trop Med Parasitol. 2005;99(1):47-52. 